\title{
From Rio to São Paulo: Shifting Urban Landscapes and Global Strategies for Brazilian Music
}

\author{
Kariann Goldschmitt, Wellesley College
}

"You need to go to São Paulo," Marcela Boechat of Dubas Música told me in 2007. She and I were meeting in Dubas's offices in the Centro district of Rio de Janeiro and she urged me, "If you really want to know about how the Brazilian music industry is responding to changes in global distribution, talk to the record companies in São Paulo." I had been running around Rio de Janeiro for months, interviewing funcionários (industry workers) to find out how they were responding to changes in the international demands for Brazilian music. At the time, I had good reason to focus my research on Rio de Janeiro. For much of the $20^{\text {th }}$ century, Rio was the locus of Brazil's most celebrated musical developments and the birthplace of the country's music industry. Urban samba, a genre that developed in the late nineteenth and early twentieth century through a mixture of Afro-Brazilian styles with cosmopolitan genres such as polka and tango, famously solidified in the city's Praça Onze neighborhood. ${ }^{1}$ By the 1930s, dictator Getúlio Vargas coopted samba and it became the official musical style of the country. Bossa nova later developed in the city's richest beachside neighborhoods in the South Zone before it became one of the most popular styles of the 1960s. To date, many of the country's most celebrated musical stars have lived there. ${ }^{2}$ While Rio's place in Brazil's national narrative is far from limited to

\footnotetext{
${ }^{1}$ For more on the history of samba in Rio de Janeiro, see Vianna (1999); Sandroni (2001); McCann (2004); Hertzman (2013).

${ }^{2}$ See Frederick Moehn (2012) for a study of recent musicians coming out of the Rio de Janeiro MPB (música popular brasileira) scene.
} 
music, ${ }^{3}$ it is the city's musical life that the government regularly touts to tourists; the country repeatedly celebrates Rio as having the best carnival celebrations, and the international airport is named after Antônio Carlos Jobim, the world famous bossa nova composer. From this perspective, the record industry in São Paulo (or any other Brazilian city, for that matter) has for the most part escaped the attention of casual observers and scholars. ${ }^{4}$ Yet, by all accounts, the music scene in São Paulo was becoming a hotbed of creative energy and the city was soon the subject of music press attention, nationally and internationally. ${ }^{5}$ As I soon learned, the emerging international visibility of the music scene in São Paulo is part of larger strategic changes among independent record labels after years of uncertainty and reorganization.

Brazil's international reputation has been in flux ever since the early 2000s. For much of the $20^{\text {th }}$ century, Brazil and Rio de Janeiro were synonymous in international discourse. Yet, as the country began to court investors and tout its economic strength, São Paulo began to compete with Rio for the limelight. At the height of the Lula (Luiz Inácio Lula da Silva) administration (2002-2010), Brazil was changing how it positioned itself in the world. When I first arrived in São Paulo in 2008, I witnessed the beginning of a geographic reordering of the interconnections between new music scenes and cultural policy in that city. By the time Brazil was preparing the host the 2014 FIFA World Cup and the 2016 Summer Olympics, those changes had solidified.

\footnotetext{
${ }^{3}$ In addition to being an important site of tourism and musical life, Rio de Janeiro was the national capitol of Brazil from 1763 to 1960.

${ }^{4}$ To date, the majority of English language scholarship about Brazilian music is on the legacies from Rio de Janeiro and the country's northeast region.

${ }^{5}$ Galletta (2016) argues that the São Paulo scene started gaining attention in Brazilian publications in 2009/2010. I witnessed signs of it during my first visit in 2008. For international examples, see coverage by U.S. public radio, the BBC, and The Guardian: "AfroPop Worldwide: The Soul of São Paulo" (24 Dec 2012), Rocha (2012), Jonze (2014).
} 
No longer did the country emphasize the musical traditions coming from Rio de Janeiro with the fastidiousness that I first witnessed in 2007. Within five years, the country was finding ways to celebrate and promote genres more associated with urban youth in major cities around the world, such as hip-hop, "indie" rock, and electronic dance music.

These maneuvers signaled that Brazil's international brand was diversifying, and they inevitably translated to what kinds of music scenes would thrive or fail. This chapter argues that the degree to which musical institutions support the geographic shift from the tourism-friendly Rio de Janeiro to São Paulo, the largest city in South America, is an index of how they choose to disrupt and transform notions of national essences in Brazilian music. Along with increased media enthusiasm for the independent scenes based in São Paulo, some cultural policy organizations along with labels and promoters are increasingly emphasizing the cosmopolitan aspects of São Paulo through larger musical changes in terms of what appears on the international stage. To put it another way, Brazil's musical brand has shifted to emphasize genres and styles closely linked to São Paulo and the kind of cosmopolitanism that city embodies.

In the course of my research into the Brazilian music industry, I have witnessed a geographic reordering of the interconnections between new music scenes and cultural policy in São Paulo. In what follows, I discuss the growth and emergence of an independent popular music scene coming from that city and how it relates to changing notions of Brazil's nation brand. These observations are part of a much larger project on how Brazilian music mediates the nation brand based in ethnographic and archival research.

\section{The New Sounds of São Paulo}

For the last decade, the nova geração or new generation of Brazilian popular music has 
showcased São Paulo's diversity and musical experimentalism. As Thiago Galletta (2016) argues in his thorough study of the scene, this emerged out of a combination of the new opportunities afforded by social media as well a concentration of performance venues, independent record companies, and a desire to move beyond the limitations of the sounds based in Rio de Janeiro. Included in this group is Boss in Drama, the stage name of Péricles Martins. His first single, "Favorite Song," found its public through its circulation through music blogs and services like Soundcloud and MySpaceMusic. Within months, Boss in Drama was receiving attention by outlets like Justin Timberlake's web site and he began remixing high profile U.S. based artists such as N.E.R.D. and Miami Horror (Young 2009). Boss in Drama, in many ways, hailed the extreme version of the cosmopolitan sound coming out of São Paulo at the end of Lula's presidency. His music is better classified as electro, disco funk, or synth-house rather than anything referencing iconic Brazilian genres. In fact, the only hint that Boss in Drama might be from Brazil is the fact that the overwhelming majority of comments on his Soundcloud mixes and YouTube videos are in Brazilian Portuguese. Otherwise, one could easily mistake his music for the latest record by French dance music artists such as Justice or Daft Punk.

Another artist with similar roots and international hype is Karol Conká. Karol Conká initially generated buzz through her MySpace page and leveraged her following to launch a recording career. Although initially from Curitiba, Conká has found most of her success via the venues and infrastructure in São Paulo perhaps best expressed in her collaborations with the hiphop production duo Tropkillaz. Since the release of Batuk Freak in 2013, she has rapidly become one of the country's top entertainers and has gained significant international attention as 
well, including from the likes of tastemakers Pitchfork and NPR. ${ }^{6}$ That same year, she collaborated with Boss in Drama on a song called "Tudo Doida," which positioned both artists in the emerging global bass scene. ${ }^{7}$ Like many of the artists in the nova geração working in São Paulo, Conká has licensed her music to appear in video games such as FIFA '14 and FIFA '18 and has courted co-branded relationships, including a deal with Skol Music, a musical venture from the Brazil beer company. As a sign of her viability in among national and international audiences, she signed with Universal Music Brasil and has appeared widely on Brazilian television as a controversial figure in the feminist movement. She also performed as part of the Summer Olympics in 2016.

Some nova geração artists rely on different networks to connect with international fans and artists. For example, the indie soul rock group Garotas Suecas toured the eastern half of the U.S. on numerous occasions while also focusing much of their attention on New York City. Through their time in the Northeast United States, they developed a following. On the other hand, the electronic dance music group Zémaria spent much of 2005 through 2010 touring Europe. Both groups paid special attention to the SXSW Music and Arts conference in Austin, TX with Garotas Suecas playing numerous shows during the duration of the 2009 festival. SXSW plays an important role in bringing together different independent artists in the same location, and in recent years, it has become a part of Brazilian cultural policy through BM\&A (Brasil Música e Arte), an organ of the government's office to promote commodity exports APEX-Brasil (Associação Brasileira de Promoção e Exportação - The Brazilian Trade and

\footnotetext{
${ }^{6}$ Batuk Freak made Pitchfork critic Jessica Hopper's top 10 albums of 2014 and songs from the album appeared on NPR alt.latino in May 2014 and February 2015.

${ }^{7}$ For a thorough critique of the discourse around global bass, see Font-Navarette (2015).
} 
Investment Agency), to encourage musicians to attend such high-profile international music conferences.

Other artists form a strong core of the new generation. In the early years of the scene, they often performed together in impromptu concerts, and it is not unusual to see their names appear in the credits for each other's work. For many, the essence of the nova geração includes singer-songwriters such as Tulipa Ruiz and Céu, rappers Emicida and Criolo, and the afro-beat influenced groups Metá Metá and Bixiga 70, among others. In addition to receiving substantial attention from the national press, they have also nurtured international audiences and licensing deals, especially in Western Europe.

\section{Changing Brazil's National Music Brand}

The change in geographic emphasis in intricately tied to aspirations to shore up Brazil's national brand. As Melissa Aronczyk (2013) notes, countries invest in their brand to bolster their economy through attracting investors and tourists, drawing from the expertise of a transnational group of branding consultants, authors, and gurus she calls "the transnational promotional class." She further argues that governments invest in their nation brand through "soft power" assets such as cuisine, film, and music to increase their diplomatic power. ${ }^{8}$ Many nations hire nation brand consultants to bolster their country's image on the global stage. Brazilian sociologist Michel Nicolau Netto (2016) traces Brazil's investment in its nation brand to the end of Lula's first term as president in 2005 when Embratur (Ministry of Tourism), released a new logo for Brazil. It is significant that Brazil moved away from the Brazilian national flag at this juncture given how

\footnotetext{
${ }^{8}$ For more on "soft power" in contrast with military power, see Nye (2004).
} 
recognizable the flag is in global commodities linked to Brazil, such as havaianas flip-flops and football jerseys.

It makes sense that Brazil would have invested in a new logo since $21^{\text {st }}$ century brand maintenance relies on a logic mediated by semiotics. Branding can now encompass everything from an individual's use of social media to speech patterns and catch-phrases. That branding encompasses such a diversity of behaviors and public presentations is yet another sign of neoliberal capitalism's so-called "marketization of everything." Although many people have a good idea of how branding works, the concept merits some unpacking so that we can better understand how it works in relation to music, city, and nation in Brazil.

Due to the nature of social media and digitization, brands in the twenty-first century function less as a combination of slogans, logos, type-faces, and jingles than media unto themselves. They circulate, they reflect, and they are uniquely suited to an age of new, social media and come into being through consumer use and experience. Scott Lash and Celia Lury (2007, p. 7) argue that brands are their own form of communication. This iteration of productconsumer interaction is a recent consequence of a media-saturated marketplace. In this crowded landscape, brands compete for public attention and loyalty, often relying on deeply ingrained associations and sign-values to do their work (Danesi, 2006; Baudrillard, 1981). When a brand dominates its market, it essentially functions as a metonym for the good or corporate entity in question - for example, Kleenex as the name for all varieties of facial tissue or Xerox for all photocopies and copying processes - where the brand's signification of difference and prestige (or dependability) overtakes all others through poetic logic (Danesi, 2006, pp. 114-116).

For much of Brazil's history, its brand has been tied to the geography and popular music of Rio de Janeiro. Musical genres such as samba and bossa nova function as metonyms both for 
the city and the country. These linkages are most evident in descriptions of Brazilian pop-rock musicians, athletes, and actors who are often described by the international press as embodying samba through physical movements and musical gestures. In this case, the representational rhetoric around samba/bossa nova, Rio de Janeiro, and Brazil works through naturalization and eroticization especially as it pertains to the image of the mulatta dancing in the annual carnival celebrations (Spurr, 1993). In this case, the semiotics of nation branding rely most heavily on stereotypes, essentialism, and the loss of linguistic nuance. It is a type of translation that occurs in branding the city and nation through music. Post-colonial theorist Dipesh Chakrabarty notes that the act of translation, especially between cultures with differing levels of power, is never neutral (2000). Here, we can see that translations bound up in minority histories are a vexing problem due to how discourse increasingly relies on metonym and an assumption of a one-to-one correspondence in translation. This can result in sometimes damaging epistemological shorthand for the cultures involved. The assumptions that go into cultural translation risk homogenizing and universalizing the thrust of global capital, thereby making it all the more imperative that we avoid "the scandalous aspects of our unavoidable translations" (Chakrabarty, 2000, p. 90). That homogenizing tendency is laid bare when nations attempt to brand ethnic or national identities through metonymy as Brazil has done with samba, its related genres of bossa nova and MPB, and their links to a discourse of cultural diversity. ${ }^{9}$ As a Brazilian Portuguese word, samba can mean any number of dance music styles (i.e. samba de côco, samba de roda) and it is only the urban style popularized in Rio de Janeiro in the early 20th century (which only coalesced in the 1930s) that is globally promoted as integral to Brazil's international brand.

\footnotetext{
${ }^{9}$ See Comaroff and Comaroff (2009) for a thorough exploration of ethnicity in nation branding.
} 
Rio's status as the hub of Brazil's most cutting-edge musical genres, and by extension, its nation brand, has been contested for quite some time given that other major city centers such as Salvador, Recife, Belo Horizonte, and São Paulo have also been home to important national trends in Brazilian popular music history. It is also significant that a vanguard of MPB artists in Rio de Janeiro have embraced what Frederick Moehn describes as an "aesthetics of mixture," where the technologies of mixing in the studio reflect the promiscuous social mixing that is so crucial to Rio de Janeiro's MPB scene. In recent years, São Paulo's cultural reputation has shifted from being the driver of finance and international trade to also being a hotbed of globally oriented culture, including cuisine, fashion and music. In fact, as Brazil's international status reached toward the stratosphere at the end Lula's second term, all eyes (and ears) turned to São Paulo. Given this change, it is not surprising that some of Brazil's best-known independent record companies as well as the country's music press reoriented their focus to São Paulo's music scenes with some labels even relocating their offices to strengthen business there and play off the city's reputation as a thriving cosmopolis.

Consider the case of Deckdisc. It is one of the most influential independent record companies in Brazil and has been associated with promoting MPB, regional music, samba, and rock/pop. In 2010, the company announced big changes: it launched a new record label dedicated to urban and "indie" music called "Vigilante;" it also dropped the "disc" in its name to better reflect the changes that had overtaken the record industry since the advent of the MP3 and the decline of the compact disc. All subsequent new releases would be on vinyl and through YouTube - a service that is easily accessible to smartphones. At the time, Fábio Silveira from Deck's new technological operations unit, explained to me that the company would also deemphasize its offices in Rio de Janeiro in favor of São Paulo, which by this point was the main 
hub of the indie and urban spirit that had been building all over the country. He made pains to highlight Boss in Drama (discussed above) when he explained the kind of posture Vigilante would take (Silveira, 2010). It was a symbolic and practical move that underscored the musical, technological, and geographic reorientation of the record industry in the years since the advent of the MP3 that de-emphasized the traditional Brazilian sounds linked to samba and bossa nova. Although the São Paulo-based indie cosmopolitanism of Vigilante did not last for more than a few years, it signaled a reorientation in the musical hierarchies of the country. The company has continued to sign artists affiliated with the São Paulo scene, such as Karol Conká and Agridoce.

There is also the example of São Paulo's YBMusic and its partnership with Selo Instituto and the nurturing role the company played in the São Paulo scene during the first decade of the $21^{\text {st }}$ century. YB's first major successes capitalized on an "aesthetics of mixture" and the rising status of the nova geração of Brazilian popular music. - YB's back catalog includes standard MPB as well as compilations that combine drum ' $n$ ' bass with other musical approaches, such as the Northeastern genres of forró, embolada, and samba de côco, the most famous of which is a drum 'n' bass tribute to forró legend Luiz Gonzaga, Baião do Viramundo [2000]. Beginning in 2005, YB considerably changed its approach toward licensing its catalog for use in television commercials and video games while seeking out international licensing and distribution deals for its artists. As such, it is one of the few record companies to thrive in a post-CD musical economy. YB's emphasis in synchronization licenses influences A\&R and production decisions with the viability of an artist often resting on whether or not they will find a place in a FIFA video game. In this sense, then, the label is a Brazilian version of the convergence of art and commerce that Tim Taylor (2012) describes between the advertising and record industries. YB's partner, Selo Instituto, was the label associated with the production collective Instituto made up 
of producer-DJs Rica Amabis, Tejo Demasceno, and Daniel Ganja Man. Their music drew from hip-hop and electronica in equal parts. All members of Instituto are now highly successful on their own in the national music scene, with Ganja Man's working partnership with hip-hop MC Criolo being the most prominent.

In 2008, label owner Maurício Tagliari explained to me that YB's success and its relationship with Instituto played a major role in the nascent São Paulo scene that would soon be described as the nova geração. This new scene was indebted to a unique, publicly supported musical infrastructure made up of bars, medium sized commercial music performance venues, record labels, and publicly funded venues. The largest category of these in São Paulo are a network of venues funded by state business taxes called SESCs (Serviço Social do Comércio, or Social Service of Commerce). SESC performance venues developed out of an initiative that began in 1946 to promote the "bem estar social" or "social well-being" alongside professional education to ease the tensions between capital and work. The SESCs in São Paulo have more resources due to the fact that São Paulo is a major business hub. It is clear that the nova geração coming out of São Paulo leans heavily on the SESCs due to the reliable income and infrastructural support such as good sound and lighting. Other publicly supported venues in São Paulo include the Centro Cultural do São Paulo (CCSP), which functions partially as a library, community education space, and music venue. There is also the Auditório Ibirapueira in the center for the city's Ibirapueira park. When I first spoke to former indie music producer Pena Schmidt in 2010, he headed programming the Auditório. At the time, he stated that the job of the venue was to be a "public stage" for Brazil - to showcase the best of Brazil's musical diversity. When I spoke with him again in 2015, he had been working for the CCSP for a year to incorporate more community involvement in its programming, such as providing a space for hip- 
hop dance groups to rehearse and hosting free-style rap competitions.

While Deck moved the locus of its strategic operations to São Paulo, YB’s prominent place in São Paulo is mostly expressed through its operational flexibility. As I have noted elsewhere, financial survival in the new Brazilian music industry increasingly relies on a tactical nimbleness and flexibility that many describe in the terms of guerrilla warfare (Goldschmitt 2014). At the same time, much of the music that is coming out of a São Paulo-focused record industry also reflects a more fundamental type of mobility - the city's industry is home to famous musicians, producers, and executives who originally hail from other parts of the country and the world. Much like Rio de Janeiro, São Paulo is a common destination for migrants seeking better economic opportunities and collaboration. It is a hub for creative music-making, and musicians who have productive careers in other parts of the country are attracted to prospect of creative collaborations in the São Paulo scene. Some prominent examples include Lucas Santtana from Bahia (current resident of Rio de Janeiro), Fernando Catatau of the band Cidadão Instigado from Pará, as well as numerous musicians from Recife and Salvador: Dengue and Pupilo of mangue-beat/rock group Nação Zumbi, Siba, DJ Dolores, and BaianaSystem. The ties these musicians maintain with other parts of the country are so well-known to music critics and journalists that their appearance on an album can sometimes signify an album's investment with the whole of the Brazilian landscape.

\section{The Geographies and Business of Cosmopolitanism}

Early into my interview with former Trama records employee and independent record label owner Eduardo Ramos, he commented on the character of São Paulo, its relationship to musical trends with the rest of the country and, by extension, the rest of the world. While 
discussing the difficulties of getting Brazilians to listen to indie music from other countries and launching new bands, he commented about the nature of music in São Paulo as a city:

There's a problem in Brazil. People are interested [in independent music], and they have an open mind, and all of this history with 'hollow' things here... I think the big thing is to forget São [Paulo] - because São Paulo is primarily a city like New York or London or Tokyo. It's like a cosmopolis. It's not a rule, but to really get to know Brazil, you have to leave São Paulo. Seriously. (Ramos, 2008) In that moment, Ramos made a connection between the spirit of São Paulo as being on par with other major world cities. São Paulo's elevated status as a major global city makes it unique compared to the rest of Brazil and that carries consequences for artists who were seeking to connect to a national audience. His use of "cosmopolis" places the indie scene there into a larger network of global cities that deemphasized an aesthetics mixture and valorized the city's connections to international finance.

As a concept, cosmopolitanism has been both celebrated and vilified by cultural critics. As Sarah Collins and Dana Gooley note, music scholars are particularly interested in teasing apart the many possibilities of new cosmopolitan critical discourse because the concept has been so crucial in the history of music all around the world (2016). Music, in particular, is an especially rich sight for expressing a cosmopolitanism in music simply due to the fact that many professional musicians must tour to support themselves and are constantly "traveling-indwelling, dwelling-in-traveling” as James Clifford so memorably described that liminal state (1997, p. 36). Scholars such as Thomas Turino (2000) and Motti Regev (2013) have explored the tension between cosmopolitan and nationalist postures in local musical styles. Often the give and take between nation and cosmopolis results in numerous tensions between international 
genres, valorized national genres, and local position-taking where the fusions of global, local and those of the state become a crucial expression of music-making (Rommen, 2007; Toynbee and Dueck, 2011). In these cases, nationalism and cosmopolitanism mutually construct and reinforce local identities in a global music market. Regardless of how enticing cosmopolitan approaches are, musicians will generally express a local flavor in keeping with the immediacy of the place in question. In most cases in Brazil, the kind of cosmopolitanism we is is "from below" (Stokes, 2010) in that it is not directly influenced by state ideology; yet, due to the machinations of staterun cultural policy, the musicians taking cosmopolitan poses in São Paulo receive indirect state support. The particular paulistano flavor of cosmopolitanism expresses the desire to communicate locally and take part in viable international trends.

For Ramos, São Paulo's cosmopolitanism is an asset - it contributes to the vibrant urban music coming out of the city - while it is also a liability by leaving paulistanos alienated from the rest of the country. São Paulo residents have different tastes and attitudes than the rest of the country and this has a direct influence on the ability for musicians to build a broader public. São Paulo's cosmopolitanism is not the same as the types of cosmopolitanisms that occur in other parts of the country. Rio de Janeiro's cosmopolitanism developed out of its port city status and embrace of certain types of international cultures. For much of the twentieth century, for example, Rio de Janeiro was especially enamored with Paris to such an extent that it influenced city design and numerous French phrases entered local vocabulary (Castro 2004, p. 138-139). Cristina Magaldi (2009) has argued that Rio's status as a port city and capital made it the first stop for immigrants (and migrants from other regions) looking for work which, in turn, allowed cariocas to feel especially connected to cosmopolitan life oriented to Parisian tastes. This allowed for an enthusiasm for musical styles from Europe, including polka and scottische among 
others, and, as Hermano Vianna (1999) has argued, it set the tone for Parisian tastes to influence the eventual valorization of urban samba as a national style. For a time, Rio was the global face of the country with a citizenry especially open to French ideas of citizenship, city design, and musical relations between center and periphery.

While Rio continues to be well globally connected, São Paulo's cosmopolitanism is of an altogether different kind. The city is a financial center, not a tourism center. Its increasing preference for the security of high walls and clear divisions between the city center and periphery are erasing Baron Haussmann's modern ideal of boulevard's free-flowing anonymity, individuality, and egalitarian public spaces (Caldeira 2000, p. 214; Caldeira 2014). São Paulo is also distinct from Brazil's coastal cities due to its location on top of a mountain; it lacks geographic features such as cliffs, canals, and beaches to limit its growth, which is part of the reason why it has been able to expand to the largest mega-city in South America. The only jungle in São Paulo is the urban jungle, with its skyscrapers and own stamp on the burgeoning world of street art. São Paulo also has its own tradition of fostering cultural vanguardism, beginning with the Semana de Arte Moderna in 1922, a cultural event that many critics consider to be the beginnings of a unique, Brazilian modernism (Johnson 1994; Wisnik 1977). This in turn later served as a muse to the countercultural music and art movement tropicalismo of the late 1960s, with musical iconoclasts such as Rita Lee and Tom Zé choosing to live in the city's Perdizes neighborhood. It is therefore no surprise that Ramos's cosmopolis is as unique to São Paulo as cosmopolitanism is in other parts of the world.

The cosmopolitanism in São Paulo is due in part to the rising status inherent to global cities. Indeed, one way to explain these socio-cultural changes is through the reordering of the global economy around major cities rather than nation states (Beck 2008). Cities are becoming 
strategic centers as they hold more global power and can be far more influential than nationstates (Calder and Freytas 2009). These major cities, such as London and New York, form interurban networks out of the need for coordinating the global economy (Sassen 2001). Top cities are largely located in the richest regions with the longest histories of international influence (and connections to colonialism), with cities in the global south ranked beneath them revealing hierarchies of influence that mirror histories of imperialism (Sassen 2002). The rapid urbanization of cities in the BRICS, the emerging economies that have the potential to rival Europe and the United States, demonstrates the tension between status and economic growth (Turok 2014). São Paulo regularly ranks as a global city, even though it is often outpaced by others in the Global North and Asia.

The connections between São Paulo and other influential and global cities in Latin America are fairly well established even as these cities continue to have friendly rivalries that are strongly tied to international sports (the most evident of these is between Buenos Aires, São Paulo and Rio de Janeiro). Despite that issue, many of the musicians who are part of the new Brazilian music industry have formed transnational networks with musicians in other major Latin American cities, such as Santiago de Chile (Garland 2014). These links also influence how the music is marketed. As freelance music marketer Sérgio Martins explained to me in 2007, Buenos Aires is one of the first major destinations of the artists that he promotes abroad, even when he does not consider the artist as being viable in English-speaking markets. This likely has to do with more openness for artists who fall outside of Brazil's traditional musical brand in countries that speak Romance languages.

Another possible explanation for the explosion of public support for São Paulo’s version of cosmopolitanism is linked to Brazil's most significant cultural policy known as incentive 
laws. At the end of 1991, the Brazilian government passed "A Lei de Incentivo à Cultura," or "the cultural incentive law" (also popularly known as "Rouanet's Law" for the former Secretary of Culture, Sérgio Paulo Rouanet). The law gives business tax incentives to invest in culture. In exchange for cultural patronage, the businesses pay less corporate tax and they get to have their name attached to outputs, thereby increasing public goodwill and strengthening their brand. Some of the first major corporations to take advantage of the new laws were those that were former state assets, such as Banco do Brasil and Petrobrás. Other banks joined, such as Caixa and Itaú. As Galletta (2016) notes, the amount of corporate resources flowing to cultural production increased at regular intervals starting in 1995. This is most obvious when viewing a Brazilian film, album, or in the last few years, a musician's personal website. In São Paulo, some corporations such Red Bull and Skol have used the incentive laws to build musical ventures as a loss-leader.

The links between global cities are also strong within Brazil with the link between São Paulo and Rio de Janeiro often dubbed an "eixo" or axis of cultural production due, in part, to the proximity of the two cities compared to the rest of Brazil. In their English-language overview of Brazil's cultural industry, Scott Lash and Celia Lury paid almost no mention of Brazilian culture outside of Rio de Janeiro and São Paulo (2008, pp. 153-180). The Rio-São Paulo link is so pronounced, in fact, that musicians and producers outside that sphere of influence formed a music collective named "fora do eixo" (off-axis circuit) to promote its artists while calling attention to the disproportionate level of power of those two cities in Brazilian musical production. The irony is that the majority of fora do eixo's activity occurs in São Paulo and Rio de Janeiro. While the collective promotes a wide range of musical styles, the collective members work together to share resources to help everyone succeed in making music beyond the typical 
routes of production, distribution, and performance (Furtado 2010; Portal Fora do Eixo 2011). Ironically, As Shannon Garland (2012) has shown, Fora do Eixo is controversial among São Paulo networks of indie musicians due to the collective's lax attitudes towards musical labor and aesthetics.

Musicians and record industry executives in São Paulo also have strong links to global cities in other continents, especially global city models New York and London, which undoubtedly influences their tastes and decisions. Eduardo Ramos relayed that he travelled to London over 60 times between 2000 and 2005 and that he has more friends there than in Salvador, Bahia. Similarly, many musicians themselves have strong connections with New York as that city has a large Brazilian American population as well as numerous music schools. The result is a musical orientation that often expresses the mobile nature of their musical choices and their tastes while affirming São Paulo’s cosmopolitanism. In recent years, numerous São Paulobased artists have established secondary fan-bases in cities such as New York and Boston. There they continue to strengthen transnational bonds and push the boundaries of what is and is not legible as Brazilian music to multiple audiences.

A good illustration of this trend is 3 na Massa. The group is made up of Rica Amabis (from the collective Instituto) and two former members of the Mangue Beat group Nação Zumbí from Recife - Dengue and Pupilo. Rica Amabis has strong ties to New York City. He and his brother, Gui (best known as Amabis in the São Paulo scene), attended music school in New York City and Instituto continued its international orientation by maintaining connections to DJ/producers there such as Kid Koala. Dengue and Pupilo have been a major part of the new sounds coming out of Brazil; they have collaborated and toured with Seu Jorge on Almaz [2010] as well as other internationally known São Paulo musicians, such as Curumin and Céu. For their 
album, the three members of 3 na Massa recruited established female vocalists and actresses to sing on their tracks resulting in a panoply of associations and mixtures, as well as songwriting collaborations between Rica Amabis and musicians who hail from a variety of pop music genres.

3 na Massa exemplifies transregional and transnational musical approaches that are increasingly common in São Paulo's new music industry. While these approaches to language, style, and urbanity indicate the change in status for the music coming from São Paulo, they only represent one major slice of how the Brazilian music industry is changing away from the popular music that has defined Brazil for much of the last century as part of its brand.

Some of the artists in São Paulo's nova geração scene indicate that the climate of the city's musical output is shifting. While the sonic markers of nation and difference were once an essential asset to any artist wishing to gain a following, this is no longer necessary. The creative milieu is so rich in that city, and so internationally oriented, that many artists are embracing the comparisons to other creative bursts from global cities. While São Paulo is not New York City, its concrete landscapes and rich immigrant communities as well as a relatively new and thriving music scene can tempt outsiders to draw parallels and wait for those musical explosions to herald new global music movements. That temptation should not blind us from recognizing that as a city, São Paulo's rise will only be an expression of financial success, and with it, the rampant expansion of neoliberalism and the continuity of certain perennial favorites, such as New York and London. As Brazil reels from the recent political and economic stability, the future of the nova geração is more uncertain than ever; however, it also points to the hope of moving the country's cultural policies away from reductive representations. 
Aronczyk, M. (2013) Branding the Nation: The Global Business of National Identity. Oxford University Press.

Baudrillard, J. (1981) For a Critique of the Political Economy of the Sign. St. Louis, MO: Telos Press.

Beck, U. (2008) Mobility and the Cosmopolitan Perspective. In: Canzler, W., Kaufmann, V. \& Kesselring, S. ed., Tracing Mobilities: Towards a Cosmopolitan Perspective. Burlington, VT: Ashgate.

Bishop, M. (2012) The Soul of São Paulo: Rock, Rap and Future Music from the Endless City. Public Radio International. 26 December.

Caldeira, T. P. R. (2014) Gender Is Still the Battleground. In: Parnell, S. \& Oldfield, S. ed., The Routledge Handbook on Cities of the Global South. New York, pp. 413-428.

Calder, K. E. \& Freytas, M. de (2009) Global Politcal Cities as Actors in Twenty-First Century International Affairs. SAIS Review, 29 (1), pp. 79-96.

Castro, R. (2004) Rio de Janeiro: Carnaval under Fire. New York: Bloomsbury.

Chakrabarty, D. (2000) Provincializing History: Postcolonial Thought and Historical Difference. Princeton: Princeton University Press.

Clifford, J. (1997) Routes: Travel and Translation in the Late Twentieth Century. Cambridge, MA: Harvard University Press.

Collins, S. \& Gooley, D. (2016) Music and the New Cosmopolitanism: Problems and Possibilities. The Musical Quarterly, 99 (2) June, pp. 139-165.

Comaroff, J. L. \& Comaroff, J. (2009) Ethnicity, Inc. University of Chicago Press.

Contreras, F. \& Diaz-Hurtado, J. (2015) Get To Know Afro-Brazilian Music With This Alt.Latino Mixtape. 15 February. 
Danesi, M. (2006) Brands. New York: Routledge.

Font-Navarette, D. (2015) Bass 101: Miami, Rio, and the Global Music South1. Journal of Popular Music Studies, 27 (4) December, pp. 488-517.

Furtado, F. (2010) Cultura Fora Do Eixo. Barbacena Online [Online]. Available from: $<\mathrm{http}: / /$ www.barbacenaonline.com.br/noticias.php?c=3989\&inf=3>.

Galletta, T. P. (2016) Cena musical paulistana dos anos 2010: a 'música brasileira' depois da Internet. Annablume.

Garland, S. (2012) 'The Space, the Gear, and Two Big Cans of Beer': Fora Do Eixo and the Debate over Circulation, Remuneration, and Aesthetics in the Brazilian Alternative Market. Journal of Popular Music Studies, 24 (4) December, pp. 509-531.

Garland, S. (2014) Music, Affect, Labor, and Value: Late Capitalism and the (Mis)Productions of Indie Music in Chile and Brazil [Online]. Columbia University. Available from: $<$ https://www.academia.edu/30682751/Music_Affect_Labor_and_Value_Late_Capitalis m_and_the_Mis_Productions_of_Indie_Music_in_Chile_and_Brazil $>$ [Accessed 26 August 2017].

Garsd, J. (2014) Knock Your Wool Socks Off With New Latin Music. 4 May. Hertzman, M. A. (2013) Making Samba: A New History of Race and Music in Brazil. Durham: Duke University Press.

Johnson, R. (1994) The Dynamics of the Brazilian Literary Field. Luso-Brazilian Review, 31 (2), pp. 5-22.

Jonze, T. (2014) São Paulo’s Music Scene: ‘Every Day Is Monday, Every Night Is Friday’. The Guardian [Online], 19 June. Available from: 
$<$ http://www.theguardian.com/music/2014/jun/19/sao-paulo-every-day-monday-everynight-friday $>$ [Accessed 10 December 2017].

Lash, S. \& Lury, C. (2007) Global Culture Industry: The Mediation of Things. Malden, MA; Cambridge: Polity Press.

Magaldi, C. (2009) Cosmopolitanism and World Music in Rio de Janeiro at the Turn of the Twentieth Century. Musical Quarterly, 92 (3-4), pp. 329-364.

Martins, S. (2007) Personal Interview.

McCann, B. (2004) Hello, Hello Brazil: Popular Music in the Making of Modern Brazil. Durham: Duke University.

Netto, M. N. (2016) Novas Forms de Associação Entre Estado e Nação: Marca-Nação e a Desestabilização de Um Hifen Na Globalização. Dossiê Capitalismo Cultura - Arquivos do CMD, 4 (2) December, pp. 11-33.

Nye, J. S. (2004) Soft Power: The Means to Success in World Politics. PublicAffairs.

Portal Fora Do Eixo (2011) [Online]. Available from: <http://foradoeixo.org.br/>.

Ramos, E. (2008) Interview.

Regev, M. (2013) Pop-Rock Music: Aesthetic Cosmopolitanism in Late Modernity. John Wiley $\&$ Sons.

Rocha, C. (2010) São Paulo Unleashes Brazilian Creative Energy. BBC News [Online]. Available from: $<$ http://www.bbc.co.uk/news/10156816>.

Rommen, T. (2007) 'Localize It': Rock, Cosmopolitanism, and the Nation in Trinidad. Ethnomusicology, 51 (3) October, pp. 371-401.

Sandroni, C. (2001) Feitiço Decente: Transformaçes Do Samba No Rio de Janeiro (1917-1933). Rio de Janeiro: Jorge Zahar. 
Sassen, S. (2001) The Global City: New York, London, Tokyo. 2nd ed. Princeton: Princeton University Press.

Sassen, S. (2002) Introduction: Locating Cities and Global Circuits. In: Sassen, S. ed., Global Networks, Linked Cities. New York: Routledge, pp. 1-38.

Schmidt, P. (2010) Personal Interview.

Schmidt, P. (2015) Personal Interview.

Silveira, F. (2010) Interview by Author.

Spurr, D. (1993) The Rhetoric Of Empire: Colonial Discourse in Journalism, Travel Writing, and Imperial Administration. Durham and London: Duke University Press.

Stokes, M. (2010) The Republic of Love: Cultural Intimacy in Turkish Popular Music. University of Chicago Press.

Tagliari, M. (2008) Interivew by Author.

Tagliari, M. (2009) Interview by Author.

Tagliari, M. (2010) Interview by Author.

Taylor, T. D. (2012) The Sounds of Capitalism: Advertising, Music, and the Conquest of Culture. Chicago: University of Chicago Press.

Toynbee, J. \& Dueck, B. (2011) Migrating Music. Taylor \& Francis.

Turino, T. (2000) Nationalists, Cosmopolitans and Popular Music in Zimbabwe. Chicago: University of Chicago Press.

Vianna, H. (1999) The Mystery of Samba: Popular Music and National Identity in Brazil. Chapel Hill: University of North Carolina Press.

Wisnik, J. M. (1977) O Coro Dos Contrários: A Música Em Torno de Semana de 22. São Paulo: Livraria Duas Cidades. 
Young, F.-A. (n.d.) Taste of Brazil: Electronic Baile Funk and More [Online]. Tennman Media Network. Available from:

$<$ http://www.justintimberlake.com/news/taste_of_brazil_electronic_baile_funk_and_mor e>. 